\title{
Bat trypanosomes from Tapajós-Arapiuns Extractive Reserve in Brazilian Amazon
}

\author{
Tripanossomas de morcegos da Reserva Extrativista Tapajós-Arapiuns na Amazônia Brasileira \\ Bruno Bernal Szpeiter ${ }^{1}$; Juliana Isabel Giuli da Silva Ferreira ${ }^{2}$; Francisco Flávio Vieira de Assis ${ }^{3}$; \\ Felipe Nascimento Stelmachtchuk ${ }^{3}$; Kleber da Cunha Peixoto Junior ${ }^{1}$; Daniel Ajzenberg ${ }^{4}$; \\ Antonio Humberto Hammad Minervino ${ }^{3}$; Solange Maria Gennari²; Arlei Marcili ${ }^{1,2 *}$
}

\author{
${ }^{1}$ Universidade Santo Amaro - UNISA, São Paulo, SP, Brasil \\ ${ }^{2}$ Departamento de Medicina Veterinária Preventiva e Saúde Animal, Faculdade de Medicina Veterinária e Zootecnia, \\ Universidade de São Paulo - USP, São Paulo, SP, Brasil \\ ${ }^{3}$ Instituto de Biodiversidade e Floresta, Universidade Federal do Oeste do Pará - UFOPA, Santarém, PA, Brasil \\ ${ }^{4}$ Biological Resource Center for Toxoplasma, INSERM, University Limoges, Limoges, França
}

Received January 17, 2017

Accepted March 30, 2017

\begin{abstract}
Trypanosoma comprises flagellates able to infect several mammalian species and is transmitted by several groups of invertebrates. The order Chiroptera can be infected by the subgenera Herpetosoma, Schizotrypanum, Megatrypanum and Trypanozoon. In this study, we described the diversity of bat trypanosomes and inferred phylogenetic relationships among the trypanosomes from bats caught in Tapajós-Arapiuns Extractive Reserve (Resex) in Pará state. Trypanosomes from bats were isolated by means of hemoculture, and the molecular phylogeny was based on the trypanosome barcode (SSUrDNA V7V8 variable region). A total of 111 bats were caught in the area, belonging to three families (Emballonuridae, Molossidae and Phyllostomidae) and 12 species. The bat trypanosome prevalence, as evaluated through hemoculture, was $9 \%$ all positive cultures were cryopreserve (100\% of isolation success). Phylogenetic trees grouped nine isolates in T. cruzi marinkellei branch and only one in $T$. dionisii branch. Studies on bat trypanosome diversity are important for identifying pathogenic species and for generating support for control measures, especially in such areas where humans inhabit the forest with close contact with bat species. In addition, this is the first study in Resex Tapajós-Arapiuns extractive reserve and further studies should be conducted to elucidate the role of these parasites as environmental degradation biomarkers.
\end{abstract}

Keywords: Trypanosoma, Chiroptera, Amazon, phylogeny, taxonomy.

\section{Resumo}

Trypanosoma compreende flagelados capazes de infectar diversas espécies de mamíferos e são transmitidos por diferentes grupos de invertebrados. A ordem Chiroptera pode ser parasitada pelos subgêneros Herpetosoma, Schizotrypanum, Megatrypanum e Trypanozoon. Neste estudo é descrita a diversidade de tripanossomas de morcegos capturados na Reserva Extrativista Tapajós-Arapiuns, no Estado do Pará. Os tripanossomas de morcegos foram isolados através de hemocultura e os estudos filogenéticos baseados na região de barcode de tripanossomas (SSUrDNA V7V8 região variável). Foram capturados 111 morcegos pertencentes a três famílias (Emballonuridae, Molossidae e Phyllostomidae) e 12 espécies. A prevalência dos tripanossomas de morcegos, avaliada por hemocultura, foi de $9 \%$ para as culturas positivas e todas foram criopreservadas (100\% de eficiência no isolamento). As árvores filogenéticas agruparam nove isolados no ramo de T. cruzi marinkellei e um único isolado de T. dionisii. Estudos sobre a diversidade de tripanossomas de morcegos sáo importantes para identificar espécies patogênicas e gerar suporte para medidas de controle, principalmente em áreas silvestres com contato entre as populaçôes humanas e de morcegos. Além disso, este foi o primeiro estudo realizado na Resex Tapajós-Arapiuns e novos estudos devem ser conduzidos para elucidar o papel destes parasitas como marcadores de degradaçáo ambiental.

Palavras-chave: Trypanosoma, Chiroptera, Amazônia, filogenia, taxonomia. 


\section{Introduction}

The genus Trypanosoma comprises protozoan flagellates that are able to infect several vertebrate species and are transmitted by several groups of invertebrates. More than 30 trypanosome species belonging to the subgenera Herpetosoma, Schizotrypanum, Megatrypanum and Trypanozoon have been described in bats (order Chiroptera) (HOARE, 1972; MARINKELLE, 1976).

The Most descriptions of the species of trypanosomes of bats are based on host of origin and morphological characters. Phylogenetic studies on trypanosomes of bats are scarce and only T. dionisii, T. vespertilionis, Trypanosoma sp. bat (isolated in Africa) and T. cruzi marinkellei were included in phylogenetic trees (STEVENS \& GIBSON, 1999; STEVENS \& RAMBAUT, 2001; HAMILTON et al., 2007). Recently, T. erneyi and T. livingstonei from African bats and T. teixeirae from flying fox in Australia were described and positioned in phylogenetic trees (LIMA et al., 2012, 2013; BARBOSA et al., 2016).

The subgenus Schizotrypanum comprises the species Trypanosoma erneyi and $T$. dionisii, which only infect bats, and T. cruzi marinkellei, which has the ability to infect many orders of mammals (MARINKELLE, 1976; LIMA et al., 2012).

T. dionisii is transmitted by bugs of the family Cimicidae, which are widely distributed, while T. cruzi marinkellei is transmitted by bugs of the family Reduviidae (Cavernicola pilosa) and only occurs in the Americas. In Brazil, the studies conducted have found T. cruzi (TCI and TcBat group), T. cruzi marinkellei and T. dionisii through hemoculture evaluations (MARCILI et al., 2009a; CAVAZZANA et al., 2010).

Trypanosoma dionisii has been detected in the bat families Phyllostomidae, Molossidae, Vespertilionidae and Noctilionidae in all biomes analyzed, from northern to southern Brazil, while T. cruzi marinkellei has been found in phyllostomid and vespertilionid bats in northern, central and southeastern areas and T. cruzi in the bat families Phyllostomidae, Vespertilionidae, Noctilionidae and Thyropteridae in the Amazon, Pantanal and Atlantic rainforest biomes (COSTA et al., 2016, 2015; ACOSTA et al., 2014; MARCILI et al., 2009a; CAVAZZANA et al., 2010). Additionally, Trypanosoma erneyi has been described in bats in Africa (LIMA et al., 2012).

There are few studies on Trypanosoma in wild mammals or vectors in the state of Pará. Trypanosoma cruzi lineages have been described in marsupials, rodents, carnivores, armadillos and triatomines (MARCILI et al., 2009a, b). New species of Trypanosoma were described recently in the bat genus Pteronotus in the state of Rondônia and in blood from bats in Pará (LIMA et al., 2015). In Altamira, T. cruzi, T. cruzi marinkellei and T. wauwau were isolated (COSTA et al., 2016). The Tapajós-Arapiuns Resex is a protected area designated for sustainable use of natural resources with difficult access with humans inhabit small villages inside the Amazon rainforest, with close contact with bats and limited information regarding trypanosome infection.

In the present study, we inferred phylogenetic relationships among the trypanosomes from bats caught in the Tapajós-Arapiuns Resex area, based on SSU rDNA sequences. Two species were described: T. cruzi marinkellei and T. dionisii from phyllostomid bats.

\section{Materials and Methods}

\section{Study areas and bats caught}

The bats were caught in the Tapajós-Arapiuns extractive reserve (Resex), mostly located in municipality of Santarem, in the Pará

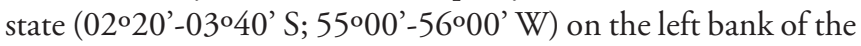
Tapajós river (Figure 1). The entire area of the Tapajós-Arapiuns Resex $(677,513.24 \mathrm{ha})$ is included in the Amazon biome (annual average temperature $27^{\circ} \mathrm{C}$; annual precipitation greater than $2400 \mathrm{~mm}$ ). More than 3000 families inhabit the area of the Tapajós-Arapiuns Resex and conduct extractive activities consisting of fishing and hunting for their own consumption (ICMbio, 2014).

Bat-catching was undertaken in each area for five nights in April 2015. Six mist nets $(7 \times 3 \mathrm{~m})$ were set up from 18:00 to 23:00 h and were checked every $30 \mathrm{~min}$ for the presence of bats. Artificial shelters on the roofs of schools were also set up and checked. The bats caught were anesthetized and blood samples were collected by means of heart puncture.

The animals were caught and manipulated in accordance with the recommendations of the Brazilian Institute for the Environment and Renewable Natural Resources and Chico Mendes Institute for Biodiversity Conservation (IBAMA-ICMBio) and the procedures used were approved by the Animal Research Committee of the University of Santo Amaro.

\section{Isolation of bat trypanosomes}

The blood samples were collected by means of heart puncture and were inoculated into vacutainer tubes containing a biphasic medium (15\% sheep red blood cells with $4 \%$ blood agar base) and liquid LIT medium supplemented with 20\% FBS (COSTA et al., 2016). The culture was incubated at $28^{\circ} \mathrm{C}$, and the isolates were cryopreserved in liquid nitrogen in the Brazilian Trypanosomatid Collection (Coleção Brasileira de Tripanossomatídeos, CBT), in the Department of Preventive Veterinary Medicine and Animal Health, School of Veterinary Medicine, University of São Paulo, Brazil. No primary samples (blood samples) were obtained to molecular diagnosis. The most caught bats were released and the amount of blood collected was prioritized for isolation.

\section{Molecular and phylogenetic analysis}

Samples of DNA from the trypanosome cultures were extracted using the phenol-chloroform method. The V7V8 barcode region of the SSU rDNA gene was amplified by means of a conventional polymerase chain reaction (PCR), as previously described (FERREIRA et al., 2008; VIOLA et al., 2008). PCR products of the expected size were purified by means of Exosap-IT (Affymetrix) and were sequenced in an automated sequencer (Applied Biosystems/PerkinElmer, model ABI Prism 3500 Genetic, Foster City, California, USA), in accordance with the manufacturer's recommendations. 
The sequences obtained were aligned with sequences that had previously been determined for other Schizotrypanum species available in GenBank, using ClustalX (THOMPSON et al., 1997), and were adjusted manually using GeneDoc (NICHOLAS et al., 1997).

The phylogenetic tree was constructed using maximum parsimony (MP) and Bayesian analysis (B). MP was implemented in PAUP version 4.0b10 (SWOFFORD, 2002) with 500 bootstrap replicates, random stepwise addition starting trees (with random addition sequences) and TBR branch swapping. Bayesian analysis was performed through MrBayes v3.1.2 (HUELSENBECK \&
RONQUIST, 2001) with 1,000,000 MCMC generations. The first $25 \%$ of the trees represented burn-in, and the remaining trees were used to calculate Bayesian posterior probability.

\section{Results}

A total of 111 bats were caught in the area, belonging to three families (Emballonuridae, Molossidae and Phyllostomidae) and 12 species (Table 1). The bat trypanosome prevalence, as evaluated through hemoculture, was $9 \%$. Ten positive hemocultures were

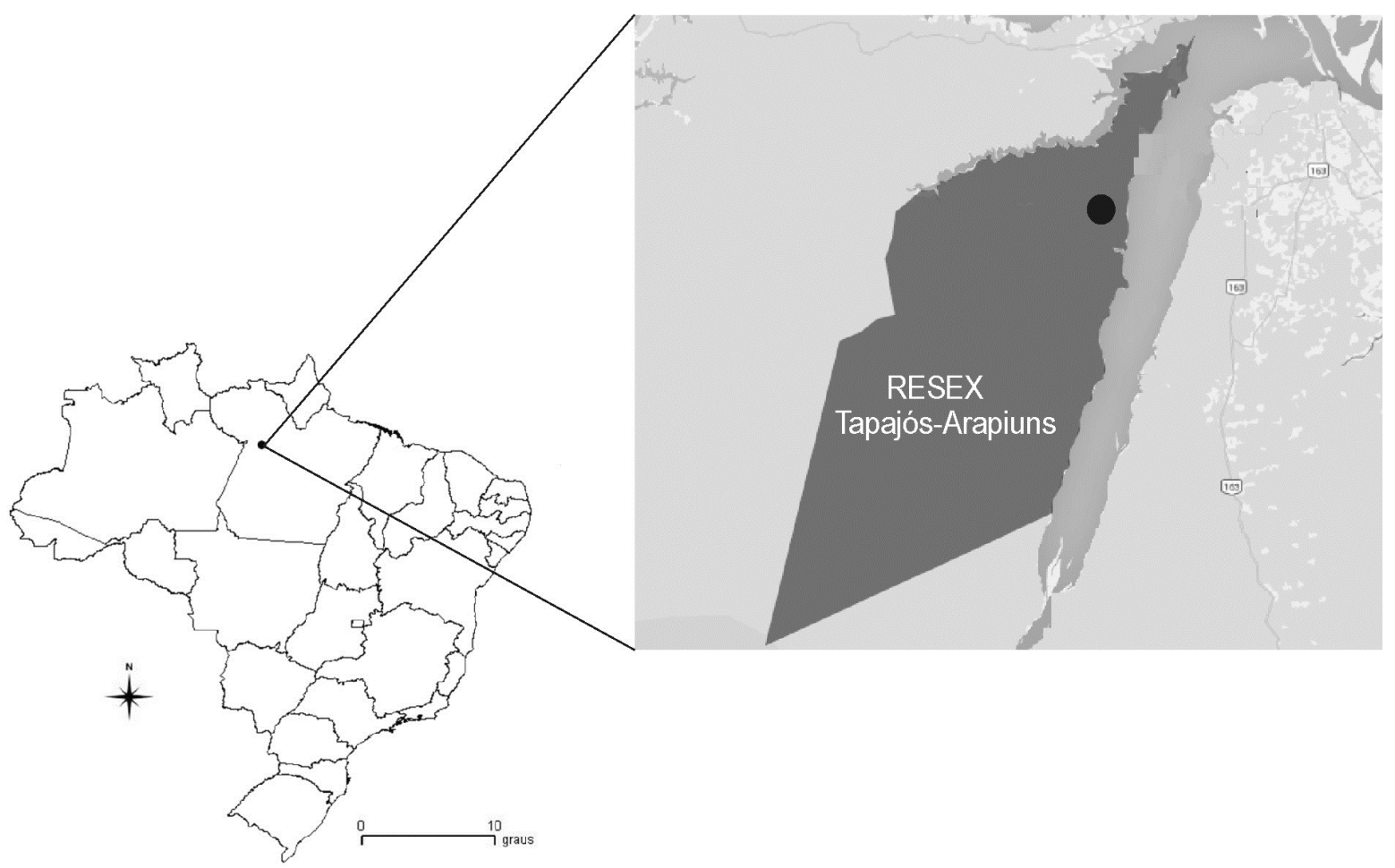

Figure 1. Map of Resex Tapajós-Arapiuns. Geographical origin of bats caught in the Resex Tapajós-Arapiuns in Alter do Chão, Pará state, Brazil.

Table 1. Hosts species and haemoculture positivity of bats examined in this study.

\begin{tabular}{|c|c|c|c|c|c|}
\hline \multirow{2}{*}{ Order } & \multicolumn{3}{|c|}{ Host } & \multicolumn{2}{|c|}{ No. of individuals } \\
\hline & Family & Genus & Species & Examined/Positive $^{a}$ & Total \\
\hline \multirow[t]{12}{*}{ Chiroptera } & Phyllostomidae & Artibeus & obscurus & $1 / 0$ & 0 \\
\hline & & Carollia & perspicillata & $51 / 8$ & 8 \\
\hline & & Glossophaga & soricina & $2 / 1$ & 1 \\
\hline & & Lichonycteris & degener & $1 / 0$ & 0 \\
\hline & & Mimon & crenulatum & $1 / 1$ & 1 \\
\hline & & Sturnira & lilium & $4 / 0$ & 0 \\
\hline & & Vampyressa & pusilla & $7 / 0$ & 0 \\
\hline & & Platyrrhinus & lineatus & $1 / 0$ & 0 \\
\hline & Molossidae & Molossus & ater & $1 / 0$ & 0 \\
\hline & & & molossus & $40 / 0$ & 0 \\
\hline & Emballonuridae & Rhynchonycteris & naso & $1 / 0$ & 0 \\
\hline & & Saccopteryx & gymnura & $1 / 0$ & 0 \\
\hline Total & 3 & 11 & 12 & $111 / 10$ & 10 \\
\hline
\end{tabular}


obtained, only from phyllostomid bats, and all of the cultures were established and cryopreserved in CBT (Table 2).

The morphology of the cultured forms and the biological behavior in culture media were similar to those of the subgenus Schizotrypanum in all isolates from phyllostomid bats.
Phylogenetic relationships based on the trypanosome barcode were inferred by means of maximum parsimony and Bayesian analysis, and congruent topologies were generated for Schizotrypanum trypanosomes (Figure 2). The subgenus Schizotrypanum is a monophyletic group (100\% of similarity of sequences, $100 \%$

Table 2. Trypanosome isolates, host and geographic origin and sequences of SSU rDNA used for phylogenetic analysis.

\begin{tabular}{|c|c|c|c|c|c|}
\hline \multirow{2}{*}{$\begin{array}{l}\text { Trypanosoma species } \\
\text { Trypanosoma rangeli }\end{array}$} & \multirow{2}{*}{$\begin{array}{c}\text { Isolate code } \\
\text { TCC643 }\end{array}$} & \multirow{2}{*}{$\begin{array}{c}\text { Host } \\
\text { Platyrrhinus lineatus }\end{array}$} & \multicolumn{2}{|c|}{$\begin{array}{l}\text { Geographic oringin } \\
\text { SSUrDNA }\end{array}$} & \multirow{2}{*}{$\begin{array}{c}\text { Acession number }^{\mathbf{a}} \\
\text { EU867803 }\end{array}$} \\
\hline & & & Miranda & MS & \\
\hline \multirow[t]{6}{*}{ T. dionisii } & CBT58 & Sturnira lillium & Pinheiros & ES & KF557744 \\
\hline & PJ & Pipistrellus pipistrellus & Belgium & & AJ009152 \\
\hline & P3 & Pipistrellus pipistrellus & England & & AJ009151 \\
\hline & TCC289 & Eptesicus brasiliensis & São Paulo & SP & FJ001651 \\
\hline & TCC633 & Sturnira lillium & Miranda & MS & EU867812 \\
\hline & CBT214 & Glossophaga soricina & Alter do Chão-Resex & $\mathrm{PA}$ & KY454457 \\
\hline \multirow[t]{4}{*}{ T. erneyi } & TCC1293 & Tadarida sp. & Mozambique & & JN040987 \\
\hline & TCC1294 & Tadarida sp. & Mozambique & & JN040988 \\
\hline & TCC1932 & Mops condylurus & Mozambique & & JN040990 \\
\hline & TCC1934 & Mops condylurus & Mozambique & & JN040991 \\
\hline \multirow{10}{*}{ T. cruzi marinkellei } & B7 & Phyllostomus discolor & São Felipe & $\mathrm{BA}$ & AJ009150 \\
\hline & CBT213 & Carollia perspicillata & Alter do Chão-Resex & $\mathrm{PA}$ & KY454456 \\
\hline & CBT215 & Mimon crenulatum & Alter do Chão-Resex & $\mathrm{PA}$ & KY454458 \\
\hline & CBT216 & Carollia perspicillata & Alter do Chão-Resex & $\mathrm{PA}$ & KY454459 \\
\hline & CBT217 & Carollia perspicillata & Alter do Chão-Resex & $\mathrm{PA}$ & KY454460 \\
\hline & CBT218 & Carollia perspicillata & Alter do Chão-Resex & $\mathrm{PA}$ & KY454461 \\
\hline & CBT220 & Carollia perspicillata & Alter do Chão-Resex & $\mathrm{PA}$ & KY454462 \\
\hline & CBT222 & Caroliia perspicillata & Alter do Chão-Resex & PA & KY454463 \\
\hline & СBT223 & Carollia perspicillata & Alter do Chão-Resex & $\mathrm{PA}$ & KY454464 \\
\hline & СВТ224 & Carollia perspicillata & Alter do Chão-Resex & PA & KY454465 \\
\hline \multirow[t]{27}{*}{ T. cruzi } & $\mathrm{Y}$ & Homo sapiens & São Paulo & SP & AF301912 \\
\hline & CLBR & Triatoma infestans & São Paulo & SP & AF245383 \\
\hline & Peru & Homo sapiens & Peru & & X53917 \\
\hline & $\mathrm{JJ}$ & Homo sapiens & Barcelos & $\mathrm{AM}$ & AY491761 \\
\hline & TCC463 & Cebus albifrons & Barcelos & $\mathrm{AM}$ & EU755224 \\
\hline & $\mathrm{NRcl} 3$ & Homo sapiens & Chile & & AF228685 \\
\hline & TCC186 & Homo sapiens & Bolivia & & FJ001630 \\
\hline & TCC862 & Euphractus sexcinctus & & $\mathrm{RN}$ & FJ183397 \\
\hline & TCC863 & Euphractus sexcinctus & & $\mathrm{RN}$ & FJ183376 \\
\hline & MT3663 & Panstrongylus geniculatus & & AM & AF288660 \\
\hline & TCC129 & Proechimys iheringi & São Paulo & SP & FJ555652 \\
\hline & TCC793 & Myotis levis & São Paulo & SP & FJ001634 \\
\hline & TCC480 & Noctilio albiventris & Miranda & MS & EU867804 \\
\hline & TCC947 & Myotis nigricans & São Paulo & SP & FJ001626 \\
\hline & TCC949 & Myotis nigricans & São Paulo & SP & FJ001627 \\
\hline & G & Didelphis marsupialis & & $\mathrm{AM}$ & AF239981 \\
\hline & TCC417 & Thyroptera tricolor & Barcelos & $\mathrm{AM}$ & FJ001631 \\
\hline & TCC711 & Didelphis marsupialis & Barcelos & $\mathrm{AM}$ & EU755229 \\
\hline & TCC1334 & Didelphis marsupialis & Parauapebas & $\mathrm{PA}$ & EU755242 \\
\hline & TCC1456 & Monodelphis brevicaudata & Pará & PA & FJ555623 \\
\hline & CBT100 & Artibeus lituratus & Chapadinha & MA & KP197161 \\
\hline & CBT146 & Philander opossum & Açailandia & MA & KP197162 \\
\hline & CBT147 & Philander opossum & Açailandia & MA & KP197163 \\
\hline & CBT148 & Didelphis albiventris & Açailandia & MA & KP197164 \\
\hline & CBT149 & Philander opossum & Açailandia & MA & KP197165 \\
\hline & CBT150 & Didelphis marsupialis & Açailandia & MA & KP197166 \\
\hline & CBT152 & Gracilinanus sp. & Açailandia & MA & KP197167 \\
\hline
\end{tabular}

${ }^{2}$ Sequences determined in this study and deposited in GenBank are underlined and bold; Brazilian states: Espirito Santo (ES); São Paulo (SP); Bahia (BA); Mato Grosso do Sul (MS); Amazonas (AM); Rio Grande do Norte (RN); Pará (PA); Maranhão (MA). 


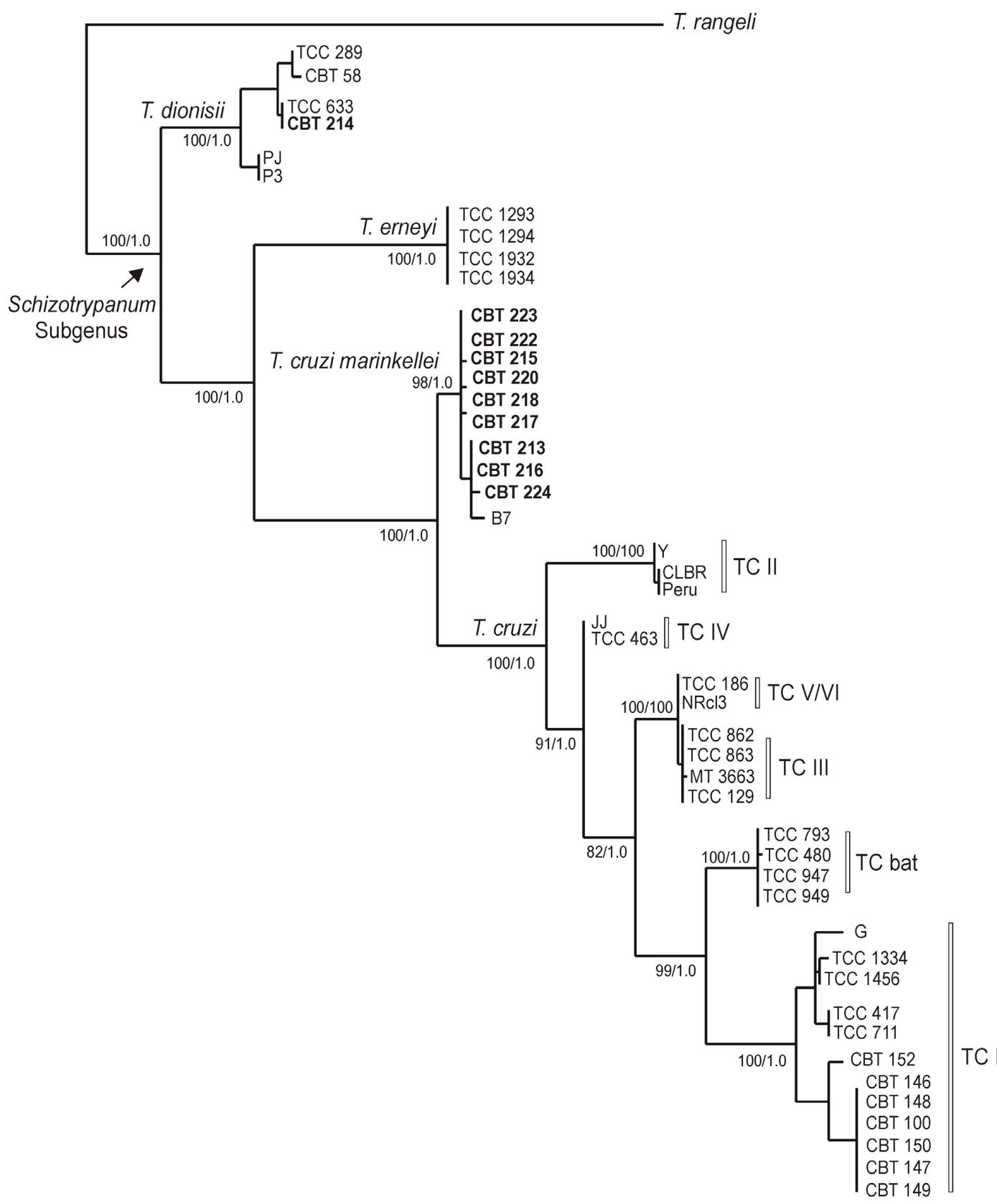

Figure 2. Phylogenetic positioning of the bats trypanosomes from Resex Tapajós-Arapiuns. Phylogenetic tree inferred by maximum parsimony and Bayesian methods of V7V8 SSU rDNA sequences from 48 trypanosomes isolates (853 characters and 62 parsimony-informative sites) from Schizotrypanum subgenus.

bootstrap and $1 \%$ Bayesian posteriori probability). The isolates obtained in this study were included in two monophyletic branches. Nine isolates (CBT 213, CBT 215, CBT 216, CBT 217 , CBT 218, CBT 220, CBT 222, CBT 223 and CBT 224) and grouped with a reference strain (B7) of T. cruzi marinkellei $(99 \%$ of similarity of sequences, $100 \%$ bootstrap and $1.0 \%$ Bayesian posteriori probability) (Figure 2). One isolate, CBT214 from Glossophaga soricina, was identified as on the T. dionisii branch with other sequences from Brazilian T. dionisii isolates $(98 \%$ of similarity of sequences, $100 \%$ bootstrap and 1.0\% Bayesian posterior probability) (Figure 2).

\section{Discussion}

The commonest infections are caused by species of Megatrypanum and Schizotrypanum and insectivorous bats are the type most frequently infected (HOARE, 1972; MARINKELLE, 1976). The trypanosome species that can infect bats and have been included in phylogenetic studies are $T$. dionisii, $T$. vespertilionis, Trypanosoma sp. bat (isolated in Africa), T. cruzi marinkellei (STEVENS \& RAMBAUT, 2001; STEVENS \& GIBSON, 1999; HAMILTON et al., 2007), T. desterrensis (GRISARD et al., 2003), T. wauwau (LIMA et al., 2015) in Brazil, T. erneyi (LIMA et al., 
2015), T. livingstonei (LIMA et al., 2013) in Africa and T. teixeirae in Austrália (BARBOSA et al., 2016).

The biomes with the highest prevalences of bat trypanosomes in Brazil are the Amazon biome with 45.2\% according to microhematocrit and hemoculture (CAVAZZANA et al., 2010) and the Amazon/Cerrado biome with 15.5\% according to hemoculture (MARCILI et al., 2013). The prevalence found in the Tapajós-Arapiuns Resex in the present study (9\%) was low in comparison with other areas and studies.

However, in the present study, all the positive samples were isolated and cryopreserved (100\% isolation success), while in other studies 20 a $35 \%$ of positive cultures did not generated isolates in several Brazilian biomes (CAVAZZANA et al., 2010; MARCILI et al., 2013; ACOSTA et al., 2014; COSTA et al., 2015, 2016).

The most isolates from Resex were positioned with T. cruzi marinkellei and only one isolate with $T$. dionisii isolates. In different studies of bat trypanosomes conducted in Brazil, T. cruzi marinkellei predominated, followed by $T$. dionisii and T. cruzi. Furthermore, T. dionisii and T. cruzi were isolated in all areas studied; meanwhile, T. cruzi marinkellei was not detected in southern or southeastern Brazil, except in Espirito Santo state (CAVAZZANA et al., 2010; ACOSTA et al., 2014).

The absence of T. cruzi isolates from the bats trypanosomes isolated from this study does not exclude their occurrence in the region. The diversity of bats species and trypanosomes associated of bats can be increase in new studies with more days, different area in Resex and sazonal variation.

Studies on diversity and associated parasites may provide information about the biology of hosts and host-parasite-environment relationships (GALLI et al., 2001; MADI \& UETA, 2012). Neotropical bats are excellent quality indicators for different ecosystems (MEDELLÍN et al., 2000; WILLIG et al., 2007).

Parasites generally respond to environmental changes faster than their hosts. This provides a means of assessing environmental stress levels and creating a density regulator for the populations of their hosts. This has a great impact on the environment and on animal communities (SILVA-SOUZA et al., 2006).

Upward or downward variations in the amount of parasitism may be an indicator of human actions within the environment that can positively or negatively influence parasite development (LAFFERTY \& KURIS, 1999). In Panamá, habitat fragmentation has increased the prevalence of Trypanosoma in the bat Artibeus jamaicensis caught in forest fragments, compared with those caught in areas of continuous forest (COTTONTAIL et al., 2009).

Studies aiming towards isolation and molecular characterization of bat trypanosomes in areas that have never previously been studied are extremely important for understanding the diversity of parasites in bats, as well as for identifying pathogenic species and generating support for control measures. In addition, studies should be conducted to confirm the role of these parasites as environmental degradation biomarkers.

\section{Acknowledgements}

This research was financially supported by Fundação de Amparo a Pesquisa do Estado de Sáo Paulo (FAPESP) and AM, AHHM and SMG from Conselho Nacional de Desenvolvimento Científico e Tecnológico (CNPq).

\section{References}

Acosta IC, Costa AP, Gennari SM, Marcili A. Survey of Trypanosoma and Leishmania in wild and domestic animals in an Atlantic rainforest fragment and surroundings in the state of Espírito Santo, Brazil. $J$ Med Entomol 2014; 51(3): 686-693. PMid:24897863. http://dx.doi. org/10.1603/ME13177.

Barbosa AD, Mackie JT, Stenner R, Gillett A, Irwin P, Ryan U. Trypanosoma teixeirae: a new species belonging to the T. cruzi clade causing trypanosomosis in an Australian little red flying fox (Pteropus scapulatus). Vet Parasitol 2016; 223: 214-221. PMid:27198803. http:// dx.doi.org/10.1016/j.vetpar.2016.05.002.

Cavazzana M Jr, Marcili A, Lima L, Silva FM, Junqueira AC, Veludo $\mathrm{HH}$, et al. Phylogeographical, ecological and biological patterns shown by nuclear (ssrRNA and gGAPDH) and mitochondrial (Cyt b) genes of trypanosomes of the subgenus Schizotrypanum parasitic in Brazilian bats. Int J Parasitol 2010; 40(3): 345-355. PMid:19766649. http://dx.doi. org/10.1016/j.ijpara.2009.08.015.

Costa AP, Costa FB, Soares HS, Ramirez DG, Mesquita ET, Gennari SM, et al. Trypanosoma cruzi and Leishmania infantum chagasi Infection in Wild Mammals from Maranhão State, Brazil. Vector Borne Zoonotic Dis 2015; 15(11): 656-666. PMid:26501369. http://dx.doi.org/10.1089/ vbz.2015.1771.

Costa AP, Nunes PH, Leite BHS, Ferreira JIGS, Tonhosolo R, Rosa AR, et al. Diversity of bats trypanosomes in hydroeletric area of Belo Monte in Brazilian Amazonia. Acta Trop 2016; 164: 185-193. PMid:27633579. http://dx.doi.org/10.1016/j.actatropica.2016.08.033.

Cottontail VM, Wellinghausen N, Kalko EKV. Habitat fragmentation and haemoparasites in the common fruit bat, Artibeus jamaicensis (Phyllostomidae) in a tropical lowland forest in Panamá. Parasitology 2009; 136(10): 1133-1145. PMid:19627629. http://dx.doi.org/10.1017/ S0031182009990485.

Ferreira RC, De Souza AA, Freitas RA, Campaner M, Takata CS, Barrett TV, et al. A phylogenetic lineage of closely related trypanosomes (Trypanosomatidae, Kinetoplastida) of anurans and sand flies (Psychodidae, Diptera) sharing the same ecotopes in Brazilian Amazonia. J Eukaryot Microbiol 2008; 55(5): 427-435. PMid:19017063. http://dx.doi. org/10.1111/j.1550-7408.2008.00342.x.

Galli P, Crosa G, Mariniello L, Ortis M, D’Amelio S. Water quality as a determinant of the composition of fish parasites communities. Hydrobiologia 2001; 452(1): 173-179. http://dx.doi.org/10.1023/A:1011958422446.

Grisard EC, Sturm NR, Campbell DA. A new species of Trypanosoma desterrensis sp. n., isolated from South American bats. Parasitology 2003; 127(3): 265-271. PMid:12964829. http://dx.doi.org/10.1017/ S0031182003003536

Hamilton PB, Gibson WC, Stevens JR. Patterns of co-evolution between trypanosomes and their hosts deduced from ribosomal RNA and protein-coding gene phylogenies. Mol Phylogenet Evol 2007; 44(1): 1525. PMid:17513135. http://dx.doi.org/10.1016/j.ympev.2007.03.023.

Hoare CA. The trypanosomes of mammals: a zoological monograph. Oxford: Blackwell Scientific Publications; 1972.

Huelsenbeck JP, Ronquist F. MRBAYES: bayesian inference of phylogenetic trees. Bioinformatics 2001; 17(8): 754-755. PMid:11524383. http:// dx.doi.org/10.1093/bioinformatics/17.8.754. 
Instituto Chico Mendes de Conservação de Biodiversidade - ICMBio. Plano de Manejo da Reserva Extrativista Tapajós-Arapiuns. Brasília: ICMBio; 2014. 141 p.

Lafferty KD, Kuris AM. How environmental stress affects the impacts of parasites. Limnol Oceanogr 1999; 44(3): 925-931. http://dx.doi. org/10.4319/lo.1999.44.3_part_2.0925.

Lima L, Espinosa-Álvarez O, Hamilton PB, Neves L, Takata CSA, Campaner M, et al. Trypanosoma livingstonei: a new species from African bats supports the bat seeding hypothesis for the Trypanosoma cruzi clade. Parasit Vectors 2013; 6(1): 221. PMid:23915781. http://dx.doi. org/10.1186/1756-3305-6-221.

Lima L, Espinosa-Álvarez O, Ortiz PA, Trejo-Varón JA, Carranza JC, Pinto CM, et al. Genetic diversity of Trypanosoma cruzi in bats, and multilocus phylogenetic and phylogeographical analyses supporting Tcbat as an independent DTU (discrete typing unit). Acta Trop 2015; 151: 166-177. PMid:26200788. http://dx.doi.org/10.1016/j.actatropica.2015.07.015.

Lima L, Silva FM, Neves L, Attias M, Takata CS, Campaner M, et al. Evolutionary Insights from Bat Trypanosomes: morphological, developmental and phylogenetic evidence of a new species, Trypanosoma (Schizotrypanum) erneyi sp. nov., in african bats closely related to Trypanosoma (Schizotrypanum) cruzi and allied species. Protist 2012; 163(6): 856-872. PMid:22277804. http://dx.doi.org/10.1016/j.protis.2011.12.003.

Madi RR, Ueta MT. Parasitas de peixes como indicadores ambientais. In: Silva-Souza AT, Lizama AP, Takemoto RM, editors. Patologia e sanidade de organismos aquáticos. Maringá: Massoni; 2012. p. 33-58.

Marcili A, Costa AP, Soares HS, Acosta ICL, Lima JTR, Minervino $\mathrm{AHH}$, et al. Isolation and phylogenetic relantionships of bats trypanosomes from different biomes in Mato Grosso, Brazil. J Parasitol 2013; 99(6): 1071-1076. PMid:23859496. http://dx.doi.org/10.1645/12-156.1.

Marcili A, Lima L, Cavazzana M, Junqueira AC, Veludo HH, Maia Da Silva F, et al. A new genotype of Trypanosoma cruzi associated with bats evidenced by phylogenetic analyses using SSU rDNA, cytochrome b and Histone H2B genes and genotyping based on ITS1 rDNA. Parasitology 2009a; 136(6): 641-655. PMid:19368741. http://dx.doi.org/10.1017/ S0031182009005861.

Marcili A, Lima L, Valente VC, Valente SA, Batista JS, Junqueira AC, et al. Comparative phylogeography of Trypanosoma cruzi TCIIc: new hosts, association with terrestrial ecotopes, and spatial clustering. Infect Genet Evol 2009b; 9(6): 1265-1274. PMid:19632356. http://dx.doi.org/10.1016/j. meegid.2009.07.003.

Marinkelle CJ. Biology of the trypanosomes of bats. In: Lumsde WHR, Evans DA, editors. Biology of the kinetoplastida. London: Academic Press; 1976. p. 175-216. vol. 1 .

Medellín RA, Equihua M, Amin MA. Bat diversity and abundance as indicators of disturbance in Neotropical Rainforests. Conserv Biol 2000; 14(6): 1666-1675. http://dx.doi.org/10.1046/j.1523-1739.2000.99068.x.

Nicholas KB, Nicholas HB Jr, Deerfield DW. GeneDoc: analysis and visualization of genetic variation. Embnew News 1997; 4: 14.

Silva-Souza AT, Shibatta OA, Matsumura-Tundisi T, Tundisi JG, Dupas FA. Parasitas de peixes como indicadores de estresse ambiental e Eutrofização. In: Tundisi JG, Matsumura-Tundisi, T, Galli CS, editors. Eutrofização na América do Sul: causas, conseqüências e tecnologias para gerenciamento e controle. 1st ed. São Carlos: Instituto Internacional de Ecologia; 2006. p. 373-386.

Stevens JR, Gibson WC. The molecular evolution of trypanosomes. Parasitol Today 1999; 15(11): 432-437. PMid:10511684. http://dx.doi. org/10.1016/S0169-4758(99)01532-X

Stevens JR, Rambaut A. Evolutionary rate differences in trypanosomes. Infect Genet Evol 2001; 1(2): 143-150. PMid:12798029. http://dx.doi. org/10.1016/S1567-1348(01)00018-1.

Swofford DL. PAUP: Phylogenetic analysis using parsimony. Beta Version 4.0610. Sunderland: Sinauer and Associates; 2002.

Thompson JD, Gibson TJ, Plewniak F, Jeanmougin F, Higgins DG. The Clustal_X windows interface: flexible strategies for multiple sequence alignement aided by quality analysis tools. Nucleic Acids Res 1997; 25(24): 4876-4882. PMid:9396791. http://dx.doi.org/10.1093/nar/25.24.4876

Viola LB, Campaner M, Takata CSA, Ferreira RC, Rodrigues AC, Freitas RA, et al. Phylogeny of snake trypanosomes inferred by SSU rDNA sequences, their possible transmission by phlebotomines, and taxonomic appraisal by molecular, cross-infection and morphological analysis. Parasitology 2008; 135(5): 595-605. PMid:18371240. http:// dx.doi.org/10.1017/S0031182008004253.

Willig M, Presley SJ, Bloch CP, Hice CL, Yanoviak SP, Díaz MM, et al. Phyllostomid bats of Lowland Amazonia: effects of habitat alteration on abundance. Biotropica 2007; 39(6): 737-746. http://dx.doi.org/10.1111/ j.1744-7429.2007.00322.x. 